\title{
KELAS ONLINE IBU BALITA UNTUK PENGETAHUAN DAN KETERAMPILAN IBU DALAM MENDETEKSI DAN MENSTIMULASI PERKEMBANGAN BALITA PADA MASA COVID-19
}

\author{
Ni Nyoman Ayu Desy Sekarini ${ }^{1}$, Ni Gusti Ayu Pramita Aswitami², Putu Irma \\ Pratiwi $^{3}$ \\ ${ }^{1,3}$ Prodi D3 Kebidanan, \\ Universitas Pendidikan Ganesha, \\ Singaraja, Indonesia \\ 2Jurusan Kebidanan, \\ Stikes Bina Husada Bali, \\ Badung, Indonesia \\ e-mail: ayu.desy@undiksha.ac.id
}

\begin{abstract}
Abstrak
Anak merupakan asset berharga bangsa sebagai penerus bangsa. Upaya mewujudkannya diperlukan lingkungan yang kondusif untuk pertumbuhan dan perkembangan yang berkualitas sejak dini. Salah satu program pemerintah yaitu dibentuknya kelas ibu balita. Namun pada masa pandemic COVID-19 pelaksanaan kelas ibu balita ditunda sampai kondisi bebas dari pandemic COVID-19. Solusi dari permasalahan tersebut adalah dengan pelaksanaan kelas ibu balita secara online atau sering disebut kelasonline ibu balita. Tujuan penelitian ini adalah untuk mengetahui efektifitas kelas online ibu balita dalam meningkatkan pengetahuan dan keterampilan ibu dalam mendeteksi dan menstimulasi perkembangan anak. Penelitian ini menggunakan rancangan Pra Eksperimen dengan pendekatan One Group Pretest-Posttest Design. Penelitian ini membandingkan pengetahuan dan keterampilan responden sebelum dan setelah perlakukan. Perlakuan yang diberikan yaitu berupa Kelas online ibu balita dengan media pembelajaran menggunakan aplikasi zoom dan Whatsapp Group. Jumlah responden yang digunakan yaitu yaitu 46 responden. Hasil penelitian diperoleh nilai $p$ value 0,000 atau $<0,05$ yang artinya bahwa kelas online ibu balita efektif meningkatkan pengetahuan dan keterampilan ibu dalam mendeteksi dan menstimulasi perkembangan Balita 0-5 tahun. Simpulan: kelas online ibu balita dapat meningkatakn pengetahuan dan keterampilan ibu dalam mendeteksi dan menstimulasi perkembangan balita.
\end{abstract}

Kata-kata Kunci: Kelas Online, Pengetahuan, Keterampilan, Perkembangan

\begin{abstract}
Children are a valuable asset for the nation as the nation's successor. Efforts to make it happen require an environment that is conducive to quality growth and development from an early age. One of the government programs is the establishment of a mother class for toddlers. However, during the COVID-19 pandemic, the implementation of the mother class under five was postponed until conditions were free from the COVID-19 pandemic. The solution to this problem is by implementing online mother toddler classes or often called online mother toddler classes. The purpose of this study was to determine the effectiveness of online classes for mothers of toddlers in increasing the knowledge and skills of mothers in detecting and stimulating child development. This study used a pre-experimental design with a One Group Pretest-Posttest Design approach. This study compares the knowledge and skills of respondents before and after treatment. The treatment given was online class for mothers of toddlers with learning media using the zoom application and the Whatsapp Group. The number of respondents used was 46 respondents. The results obtained $p$ - value of 0.000 or $<0.05$, which means that online classes for mothers of toddlers are effective in increasing the
\end{abstract}

Article History: Received 22 Juni 2020, Revised 06 Oktober 2020, accepted 30 Oktober 2020 
knowledge and skills of mothers in detecting and stimulating the development of toddlers from 0 to 5 years old. Conclusion: online classes for mothers of toddlers can increase the knowledge and skills of mothers in detecting and stimulating toddler development.

Keywords: online class, knowledge, skills, development

\section{PENDAHULUAN}

Anak-anak merupakan aset berharga bagi negara. Masa depan suatu bangsa ditentukan oleh pendidikan dan wawasan anak pada masa sekarang. Dalam upaya mewujudkan generasi bangsa yang berkualitas maka harus menciptakan kondisi yang kondusif untuk pertumbuhan dan perkembangan anak. Namun pada tahun 2020 awal Indonesia menyatakan pahwa negara mengalami pandemic COVID-19. Coronavirus Disease 2019 (COVID-19) juga dinyatakan sebagai global pandemic atau pandemic dunia. Indonesia menetapkan COVID-19 sebagai penyakit infeksi yang menimbulkan kegawatdaruratan kesehatan masyarakat serta bencana nonalam.(Yuliana, 2020). Covid-19 sangat berdampak pada kesehatan bahkan dapat menimbukan kematian. Jumlah kasus yang tercatat (20 Pebruari 2021) 1,27 juta kasus dengan 34.316 kasus meninggal. Secara tidak langsung kebijakan pemerintah dalam rangka penangulangan pandemic Covid-19 pun menimbulkan dampak pada sektor pendidikan, pariwisata dan ekonomi masyarakat.(Abdurrahman Naufal, 2020). COVID-19 memiliki dampak dalam segala aspek yang meliputi: dampak social, ekonomi, kesehatan, parawisata yang diakibatkan oleh invervensi yang dilaksanakan pemerintah dalam upaya memperlambat penyebaran COVID-19 meliputi karantina bagi orang yang terinfeksi, pembatasan perjalanan domestic dan internasional, larangan berkumpul dalam kelompok dan keramaian, serta penutupan sekolah, pabrik, restoran dan ruang public (Mufida et al., 2020). Diperkirakan tingkat kemiskinan akan meningkat menjadi $12,4 \%$ yaitu 8,5 juta orang menjadi miskin (Suryahadi et al., 2020). Keadaan tersebut secara tidak langsung mempengaruhi kegiatan sehari-hari dan aspek kehiduapan anak. Meskipun resiko kesehatan dari COVID-19 pada anak lebih rendah dibandingkan dengan kelompok usia dewasa, namun dapat mengakibatkan beragam dampak sekunder yang timbul baik dalam jangka waktu pendek atau jangka waktu panjang. Menurunnya ekonomi keluarga memunculkan berbagai dampak bagi anak usia dini meliputi: emosi anak tidak stabil, krisi gizi dan kesehatan anak, terjadi gap pembelajaran, krisis keamanan dna kenyamanan dan krisis pengasuhan anak.(Wiresti, 2020)

Intervensi yang dilaksanakan pemerintah tersebut juga mempengaruhi perkembangan anak. Keadaan yang mengharuskan anak untuk belajar dirumah (BDR) memberikan dampak pada perkembangan anak yaitu pada perkembangan kognitif dimana anak tidak dapat memahami materi secara maksima, segi bahasa anak tidak dapat menyusun kata yang baik dan benar, serka kurangnya bersosialnya anak serta motovasi belajar anak menurun.(Tunjung et al., 2020). Menurut Soetjiningsih (1995) dalam (Saadah et al., 2020), Pertumbuhan (growth) berkaitan dengan masalah perubahan dalam besar, jumlah, ukuran, dimensi, tingkat sel, organ maupun individu yang biasa diukur dengan ukuran berart, umur tulang dan keseimbangan metabolic. Perkembangan (development) adalah bertambahnya kemampuan (skill) dalam struktur dan fungsi tubuh yang lebih kompleks dalam pola teratur dan dapat diramalkan.

Perkembangan balita dipengaruhi leh beberapa faktor yaitu kondisi kehamilan, komplikasi persalinan, penemuhan nutrisi, perawatan kesehatan dan kerentanan terhadap penyakit.(Y. R. Putri et al., 2018). Seluruh faktor tersebut merupakan bagian dari peranan orang tua karena naka masih tergantung pada orang tuanya. Orang tua merupakan tempat pertama kali anak berinteraksi apabila lingkungan interaksi anak baik maka perkembangan social anak akan baik, namun jika lingkungan social anak kurang baik maka akan berdampak negatif bagi perkembangan anak.(Nandwijiwa \& Aulia, 2020). Peran orang tua dipengaruhi oleh pengetahuan orang tua tentang perkembangan anak, sehingga diharapkan orang tua memiliki pengetahuan yang baik tentang perkembangan anak sesuai usia anak.(Hasiana, 2020). . Menurut Letari (2012) peran orang tua digunakan orang tua berkaitan dengan pandangannya mengenai tugas yang harus 
dijalankan dalam mengasuh anak (Lestari, 2012). Hadi (2016) mengemukakan bahwa orang tua berkewajiban dan bertanggung jawab untuk mengasuh, memelihara, mendidik dan melindungi anak. Selain itu Hadi (2016) mengemukakan bahwa keluarga juga harus menumbuh kembangkan anak sesuai dengan kemampuan, bakat dan minat (Hadi, 2016).

Pada masa pandemic Covid-19 ini orang tua juga berfungsi dengan signifikan dalam menolong pertumbuhan dan perkembangan social anak. (Nandwijiwa \& Aulia, 2020). Pada masa pandemic COVID-19 ini diharapkan keluarga khusunya orang tua melakukan deteksi dan stimulasi perkembangan anak yang dilakukan secara mandir di rumah. Namun tidak semua orang tua balita mengetahui dan mamp melakukan stimulasi dan deteksi dini perkembangan anak. Dari studi pendahuluan yang dilaksanakan 7 dari 10 orang tua tidak mengetahui tentang stimulasi dan deteksi dini perkembangan anak degan benar. Dalam meningkatkan peran keluarga terutama orang tua (ibu) maka pemerintah membentuk kelas ibu balita untuk mengedukasi para ibu balita terkait pertumbuhan dan perkembangan anak. Menurut(Sulisnadewi et al., 2018) dalam jurnalnya menyatakan bahwa terdapat perbedaan pengetahuan, sikap dan keterampilan sebelum dan setelah ibu mengukuti kelas ibu balita. Kelas ibu balita yang seyogyanya dilaksanakan secara langsung namun, pada masa pandemi ini tidak dapat terlaksanan. Pemerintah melarang kegiatan yang menimbulkan kerumunan pada akhirnnya kegiatan edukasi dan sebagian pelayanan kesehatan dilakukan secara virtual atau pembelajaran dalam jaringan (online), sehingga solusinya adalah melaksanakan Kelas Online Ibu Balita.

Kelas online atau dapat diistilahkan pembelajaran dalam jaringan (daring) merupakan pembelajaran yang menggunakan jaringan internet dengan aksesbilitas, konektivitas, fleksibilitas dan kemampuan yang memunculkan berbagai jenis interaksi dalam pembelajaran. Pembelajaran daring juga dapat memiliki kelebihan yaitu menumbuhkan kemandirian belajar dan meningkatkan motivasi belajar serta keberanian mengemukan pendapat. (Sadikin et al., 2020). Namun terdapat kelemahan dalam pembelajaran daring meliputi kurangnya perankat teknologi dan ketersediaan jaringan internet serta penguasaan aplikasi.(Arosyd \& Usman, 2020). Menurut penelitian (Hasbi \& Sumarni, 2020) dari platform digital yang dapat mendukung pembelajaran daring terdapat empat platform digital yang sering digunakan yaitu whatsapp group, fasilitas google (google classroom, google form, google meet) dan zoom cloud meeting. Pada penelitian ini peneliti tertarik untuk melakukan penelitian efektifitas kelas online ibu balita dalam meningkatkan pengetahuan dan keterampilan ibu dalam deteksi dan stimulasi perkembangan Balita 0-5 Tahun dengan menggunakan flatform digital yaitu Zoom Cloud Meeting dan Whatsaap Group.

\section{METODE}

Penelitian ini merupakan penelitian Pra-Eksperiment dengan menggunakan rancangan One Group Pretes-Posttest Design. Variable pengetahuan dan keterampilan dalam mendeteksi dan menstimulasi perkembangan balita diukur sebelum dan setelah perlakuan diberikan. Tujuan penelitian ini yaitu mengetahui efektivitas kelas online ibu balita dalam meningkatkan pengetahuan dan keterampilan ibu dalam mendeteksi dan menstimulasi perkembangan balita (0-5 tahun). Teknik pengumpulan data yaitu pemilahan data, entry data, pengolahan data dan analisis data. Instrument pengumpulan data yang digunakan yaitu kuisioner tingkat pengetahuan dan daftar tilik stimulasi, deteksi, intervensi dini, tumbuh dan kembang (SDIDTK). Perlakuan yang diberikan yaitu dengan memberikan materi yang dilanjutkan dengan diskusi terkait perkembangan balita dengan cara online menggunakan media zoom dan whatsaap group sebanyak tiga tahap. Pertemuan pertama dilakukan secara virtual dengam media zoom yang dimulai dengan pengisian kuisioner pretes pengetahuan dan keterampilan dilanjutkan materi dan diskusi. Tahap 3 dilakukan diskusi dengan media whatshap group. Tahap 3 dilakukan dengan media zoom yang meliputi diskusi dan pengisian kuisioner posttes pengetahuan dan keterampilan. Setelah data terkumpul maka dilakukan analisi univariate dan bivariate. Analisis univariate dilakukan pada karakteristik responden berupa persentase. Analisis bivariate menggunakan T-Test Berpasangan karena data berdistribusi normal. Populasi pada penelitian ini yaitu seluruh ibu balita di Desa Dauh Peken 
Tabanan. Sampel penelitian ini yaitu 46 ibu balita di Desa dauh Peken Tabanan. Jumlah sampel diperoleh berdasarkan perhitungan rumus Solvin. Teknik pengambilan sampel menggunakan Simple Random Sampling. Penelitian dilaksanakan pada bulan September 2020.

\section{HASIL DAN PEMBAHASAN}

Pada hasil penelitian ini akan diuraikan tentang karakteristik responden dan efektifitas kelas online ibu balita dalam meningkatkan pengetahuan dan keterampilan ibu dalam mendeteksi dan menstimulasi perkembangan balita (0-5 tahun). Berikut dijabarkan hasil penelitian:

Tabel 1.

Karakteristik Responden

\begin{tabular}{lcc}
\hline \multicolumn{1}{c}{ Karakteristik lbu Balita } & N & $\%$ \\
\hline Umur & 2 & 4,4 \\
$\geq 20$ tahun & 41 & 89,1 \\
$21-35$ tahun & 3 & 6,5 \\
$>35$ tahun & 46 & 100 \\
Total & & \\
Pekerjaan & 30 & 65,2 \\
IRT & 5 & 19,9 \\
Pedagang & 0 & 0 \\
Buruh & 9 & 19,5 \\
Swasta & 2 & 4,4 \\
PNS & 46 & 100 \\
Total & & \\
Pendidikan & 2 & 4,4 \\
Dasar & 35 & 76,1 \\
Menengah & 9 & 19,5 \\
$\quad$ Tinggi & $\mathbf{4 6}$ & $\mathbf{1 0 0}$ \\
\hline Total & & \\
\hline
\end{tabular}

Berdasarkan tabel 1. dapat dilihat bahwa karakteristik responden berdasarkan umur diperoleh sebagaian besar $r 41$ (89,1\%) responden berada pada kelompok umur 21-35 tahun. Karakteristik responden berdasarkan pekerjaan diperoleh sebagian besar $30(65,2 \%)$ responden sebagai ibu rumah tangga (IRT). Karakteristik responden berdasarkan pendidikikan diperoleh sebagian besar $35(75,1 \%)$ responden dengan pendidikan menengah. Karakteristik responden berdasarkan jumlah anak diperoleh sebagian besar $22(47,8 \%)$ memiliki jumlah anak dua.

Berdasarkan hasil yang telah di analisis univariate maka dapat dilihat bahwa umur responden berada pada kelompok umur 21-35 tahun. Pada kelompok umur ini merupakan kelompok umur reproduktif yang baik untuk menerima informasi atau edukasi. Usia 21-35 tahun merupakan usia reproduktif yang berperan dan memiliki aktifitas padat serta memiliki kemampuan kognitif yang baik. Pada kelompok umur ini memiliki tingkat kemampuan yang baik.(Suwaryo \& Yuwono, 2017). Hasil penelitian juga menunjukkan dimana pekerjaan responden sebagian besar adalah sebagai ibu rumah tangga. Kegiatan ibu rumah tangga tidak dapat dikatakan pekerjaan yang mudah karena ibu mulai bekerja dari baru bangun sampai tidur kembali. Pada penelitian Putrid an Sudhana (2013) menyatakan bahwa banyak orang mengatakan masalah terkait rumah tangga adalah masalah sederhana dan mudah serta tidak banyak menyita waktu, pikiran, maupun tenaga. Namun pada kenyataannya, berdasarkan hasil penelitian tersebut diperoleh ibu rumah tangga 
yang mengerjakan seluruh pekerjaan rumahnya tanpa dibantu orang lain memiliki tingkat stress yang lebih tinggi dibandingkan dengan ibu rumah tangga yang dibantu oleh pembantu rumah tangga.(K. A. K. Putri \& Sudhana, 2013). Responden penelitian ini memiliki pendidikan terakhir terbanyak yaitu pada tingkat menengah. Semakin tinggi pendidikan seseorang semakin cepat pula untuk menerima atau menyerap informasi yang diperoleh. Berikut diuraikan pengetahuan ibu balita dalam mendeteksi dan menstimulasi perkembangan balita pada tabel 2.

Tabel 2.

Efektifitas kelas online dalam meningkatkan pengetahuan dalam deteksi dan stimulasi perkembangan balita

\begin{tabular}{cccccc}
\hline Pengetahuan & \multicolumn{2}{c}{ Pretest } & \multicolumn{2}{c}{ Posttest } & P-Value \\
\cline { 2 - 5 } & $\mathbf{n}$ & $\mathbf{\%}$ & $\mathbf{n}$ & $\%$ & 0,000* \\
Baik & 10 & 21,7 & 37 & 80,4 & \\
Cukup & 26 & 56,5 & 8 & 17,4 & \\
Kurang & 10 & 21,7 & 1 & 2,2 & \\
Mean & \multicolumn{2}{c}{0,666667} & \multicolumn{2}{c}{2,0000} & \\
Std. Deviation & \multicolumn{2}{c}{0,46729} & \multicolumn{2}{c}{1,2174} & \\
\hline Total & $\mathbf{4 6}$ & $\mathbf{1 0 0}$ & $\mathbf{4 6}$ & $\mathbf{1 0 0}$ & \\
\hline
\end{tabular}

Berdasarkan tabel 2. dapat dilihat bahwa pada saat sebelum diberikan perlakuan sejumlah $10(21,7 \%)$ responden memiliki pengetahuan baik, sejumlah $26(56,5 \%)$ responden memiliki pengetahuan cukup dan $10(21,7 \%)$ responden memiliki pengetahuan kurang. Setelah diberikan perlakuan sejumlah $37(84,4 \%)$ responden memiliki pengetahuan baik, sejumlah $8(17,4 \%)$ responden memiliki pengetahuan cukup dan $1(2,2 \%)$ responden memiliki pengetahuan kurang. Berdasarkan hasil tersebut dapat dilihat yaitu tingkat pengetahuan sebelum diberikan kelas ibu balita memiliki rata-rata 0,66667 sedangkan setelah diberikan kelas online memiliki rata-rata 2,000. Artinya erjadi peningkatan rata-rata pnegetahuan responden sebelum dan setelah perlakuan yaitu sejumlah 1,333. Hasil $p$ value diperoleh $0,000<0,005$ yang artinya kelas online ibu balita efektif dalam meingkatkan pengetahuan dalam mendeteksi dan menstimulasi perkembangan balita. Pengetahuan merupakan hasil tahu yang diperoleh dari seseorang melakukan penginderaan. Berbagai faktor yang dapat mempengaruhi pengetahuan adalah sumber informasi yang diperoleh (Notoatmojo, 2012). Sesuai dengan penelitian Tarigan (2019) menyatakan bahwa ketepaparan subjek tentang sumber informasi berhubungan signifikan dengan peningkatan pengetahuan.(Tarigan, 2019) Haryanti (2018) menambahkan bahwa sumber informasi yang diperoleh sebagian besar yaitu 27 (50,9\%) memiliki pengetahuan baik dari jumlah tersebut 17 $(32,1 \%)$ memperoleh sumber dari internet atau online (Haryanti, 2018).

Pada masa pandemic ini pelayanan kesehatan di pusat pelayanan di rumah sakit maupun di puskesmas dibatasi. Anjuran untuk menunda anak kerumah sakit kecuali dalam keadaan gawatdarurat terus disosialisasikan. Selain itu kegiatan kelas balita secara langsung pun ditunda pelaksanaannya sampai kondisi bebas dari pandemic COVID-19. Namun untuk deteksi perkembangan harus tetap dilaksanakan, dengan cara mandiri oleh keluarga atau orang tua. (Kemenkes, 2020). Kelas online ibu balita ini membantu ibu untuk meningkatkan pengetahuan dalam mendeteksi dan menstimulasi perkembangan anak. Senada dengan penelitian (Putra, 2020) menyatakan bahwa pembelajaran online dengan menggunakan penggunaan aplikasi zoom dan Whatsapp Group memberikan kemudahan dan fleksibelitas. Penguasaan pengetahuan dan keterampilan lebih efektif individu mengalaminya sendiri bukan hanya menunggu materi dari fasilitator namun harus berusaha sendiri untuk menemukan pengetahuan dan keterampilan yang 
baru dan kemudian mengitegrasikannya dengan pengetahuan dan keterampilan yag sudah dimilikiny sebelumnya. Penelitian lain juga mengungkapkan (Monica \& Fitriawati, 2020) pembelajaran online mendapat tanggapan sangat baik dari mahasiswa karena pembelajaran lebih fleksibel saat menggunakannya dan menggunakan aplikasi zoom juga sangat efektif karena banyak fitur di dalam zoom yang menjadikan pembelajaran semakin menarik. Penelitian (Gunawan, 2020) menambahkan bahwa pembelajaran oline dengan menggunakan aplikasi zoom meningkatkan hasil belajar daring pada pembelajaran tematik. Berikut diuraikan keterampilan ibu balita dalam mendeteksi dan menstimulasi perkembangan balita pada tabel 3 .

Tabel 3.

Efektifitas kelas online dalam meningkatkan Keterampilan dalam deteksi dan stimulasi perkembangan balita

\begin{tabular}{|c|c|c|c|c|c|}
\hline \multirow[t]{2}{*}{ Keterampilan } & \multicolumn{2}{|c|}{ Pretest } & \multicolumn{2}{|c|}{ Posttest } & \multirow{2}{*}{$\begin{array}{c}\text { P-Value } \\
0,000^{*}\end{array}$} \\
\hline & $n$ & $\%$ & $\mathbf{n}$ & $\%$ & \\
\hline Baik & 3 & 6,5 & 29 & 63 & \\
\hline Cukup & 5 & 10,9 & 15 & 32,6 & \\
\hline Kurang & 38 & 82,6 & 2 & 4,4 & \\
\hline Mean & \multicolumn{2}{|c|}{0,56509} & \multicolumn{2}{|c|}{2,7609} & \\
\hline Std. Deviation & \multicolumn{2}{|c|}{0,58027} & \multicolumn{2}{|c|}{1,4130} & \\
\hline Total & 46 & 100 & 46 & 100 & \\
\hline
\end{tabular}

Berdasarkan tabel 3. dapat dilihat bahwa pada saat sebelum diberikan perlakuan sejumlah 3 $(6,5 \%)$ responden memiliki keterampilan baik, sejumlah $5(10,9 \%)$ responden memiliki keterampilan cukup dan $38(82,6 \%)$ responden memiliki keterampilan kurang. Setelah diberikan perlakuan sejumlah 29 (63\%) responden memiliki keterampilan baik, sejumlah 15 (32,6\%) responden memiliki keterampilan cukup dan $2(4,4 \%)$ responden memiliki keterampilan kurang. Berdasarkan data tersebut diperoleh bahwa terdapat peningkatan nilai rata-rata responden sebelum dan setelaha di berikan kelas online ibu balita yaitu dari 0,56509 menjadi 2,7609 yang artinya meningkat 2,19581 . Hasil $p$ value diperoleh 0,000 atau $<0,05$ yang artinya kelas online ibu balita efektif meningkatkan keterampilan ibu dalam mendeteksi dan menstimulasi perkembangan balita.

Keterampilan merupakan kemampuan untuk menggunakan akal, pikiran, ide dan kreatifitas dalam mengerjakan, mengubah ataupun membuat sesuatu menjadi lebih bermakna sehingga menghasilkan sebuah nilai dari hasil pekerjaan tersebut. Keterampilan disebut juga kemampuan teknis untuk melakukan sesuatu perbuatan. Efektifitas dan efisiensi suatu pekerjaan sangat ditentukan oleh tingkat keterampilan yang dimiliki pelakunya.(Sudarto, 2016). Pembelajran online membantu dalam peningkatan keterampilan seseorang. Sesui dengan penelitian (Bahtiar et al., 2020) menggunakan media zoom dan whatshapp yang merupakan salah salah satu platform digital pembelajaran daring digunakan untuk mengetahui peningkatan keterampilan berbicara siswa melalui teknik simulasi tiga langkah. Hasil dari penelitiannya diperoleh bahwa penerapan simulasi tiga dapat meningkatkan keterampilan berbicara siswa. Senada dengan penelitian (Putra, 2020) menyatakan bahwa pembelajaran online dengan menggunakan penggunaan aplikasi zoom dan Whatsapp Group memberikan kemudahan dan fleksibelitas. Penguasaan pengetahuan dan keterampilan lebih efektif individu mengalaminya sendiri bukan hanya menunggu materi dari fasilitator namun harus berusaha sendiri untuk menemukan pengetahuan dan keterampilan yang baru dan kemudian mengitegrasikannya dengan pengetahuan dan keterampilan yag sudah dimilikinya sebelumnya. . Pembelajaran daring juga dapat memiliki kelebihan yaitu menumbuhkan 
kemandirian belajar dan meningkatkan motivasi belajar serta keberanian mengemukan pendapat. (Sadikin et al., 2020)..

\section{PENUTUP}

Simpulan dari hasil penelitian ini adalah kelas onlin ibu balita dapat meningkatkan pengetahuan dan keterampilan ibu dalam mendeteksi dan menstimulaso perkembangan balita. Dari hasil penelitian ini dapat dilihat bahwa kita dapat meningkatkan pengetahuan dan keterampilan walaupun tidak melalui pembelajaran secara langsung (tatap muka) terutama pada masa pandemi COVID-19 ini. Saran untuk peneliti selanjutnya yaitu meneliti tentang pretumbuhan balita pada masa pandemi COVID-19.

\section{UCAPAN TERIMAKASIH}

Penulis mengucapkan terimakasih sebesar-besarnya kepada Universitas Pendidikan Ganesha yang telah memberikan kesempatan dan dukungan dalam pelaksanaan penelitian ini.

\section{DAFTAR PUSTAKA}

Abdurrahman Naufal. (2020). Dampak Corona Terhadap Ekonomi Indonesia. Portal Resmi Republik Indonesia, 4(September), 384-388. https://doi.org/10.33087/ekonomis.v4i2.179

Arosyd, I. M. R., \& Usman, R. (2020). Analisis Kelemahan dan Kekuatan dalam pembelajaran daring di Fakultas Sastra Universitas Negri Malang. Journal Deutsch Als Fremdsprache in Indonesien, 4(2). http://journal2.um.ac.id/index.php/dafina/

Bahtiar, K., Harmayanthi, V. Y., \& Kusumajati, W. K. (2020). Meningkatkan Keterampilan Berbicara Siswa melalui Teknik Simulasi Tiga Langkah. Prosiding Seminar Nasional Pendidikan STKIP Kusuma Negara II, 181-187.

Gunawan, I. (2020). Peningkatan Hasil Belajar Daring Peserta Didik Selama Pandemi Covid-19 Melalui Pemanfaatan Fitur Aplikasi Zoom Di Sd Negeri 77 Palembang. Jurnal Inovasi Sekolah Dasar, 7(2), 152-163.

Hadi, A. (2016). Nilai-Nilai Pendidikan Keluarga Dalam Uu No. 23 Tahun 2002 Tentang Perlindungan Anak. An-Nisa, IX(23), 101-121. https://adoc.pub/nilai-nilai-pendidikankeluarga-dalam-uu-no-23-tahun-2002-te.html

Haryanti, T. (2018). Hubungan Pemanfaatan Sumber Informasi Dengan Pengetahuan Remaja Tentang Seksual Di Sma N.2 T. Balai. XI(1), 29-33.

Hasbi, M., \& Sumarni, W. (2020). Pemanfaatan Platform Digital di Masa Pandemi Covid-19. Seminar Nasional Pascasarjana 2020: https://proceeding.unnes.ac.id/index.php/snpasca/article/download/601/519/

Hasiana, I. (2020). Peran Orangtua Dalam Pendidikan Seksual Anak Usia Dini. Wahana, 72(2), 118-125. https://doi.org/10.36456/wahana.v72i2.2725

Kemenkes. (2020). Panduan Pelayanan Kesehatan Balita Pada Masa Tanggap Darurat COVID19. In Kementrian Kesehatan RI.

Lestari, S. (2012). Psikologi Keluarga; Penanaman Nilai dan penangan Konflik Dalam keluarga. Kencana.

Monica, J., \& Fitriawati, D. (2020). Efektivitas Penggunaan Aplikasi Zoom Sebagai Media Pembelajaran Online Pada Mahasiswa Saat Pandemi Covid-19 As An Online Learning Medium For Students During The Covid-19 Pandemic. Jurnal Communio: Jurnal IImu Komunikasi, IX(2), 1630-1640.

Mufida, S., Timur, F. G. C., \& Waluyo, S. D. (2020). Strategi Pemerintah Indonesia Dalam 
Menangani Wabah Covid-19 Dari Perspektif Ekonomi. Independen Jurnal Politik Indonesia Dan Global, 1(2), 121-130. https://doi.org/10.24853/independen.1.2.121-130

Nandwijiwa, V., \& Aulia, P. (2020). Perkembangan Sosial Anak Usia Dini pada Masa Pandemi COVID-19. Jurnal Pendidikan Tambusai, 4(3), 3145-3151. https://jptam.org/index.php/jptam/article/view/821

Putra, N. P. (2020). Solusi Pembelajaran Jarak Jauh Menggunakan Aplikasi Zoom Dan Whatsapp Group Di Era New Normal Pada Warga Belajar Paket C Di Pusat Kegiatan Belajar Masyarakat (Pkbm) Bina Insani. Jipsindo, 7(2), 162-176.

Putri, K. A. K., \& Sudhana, H. (2013). Perbedaan Tingkat Stres Pada lbu Rumah Tangga yang Menggunakan dan Tidak Menggunakan Pembantu Rumah Tangga Ketut Ariyani Kartika Putri dan Hilda Sudhana. Jurnal Psikologi Udayana, 1(1), 94-105.

Putri, Y. R., Lazdia, W., \& Oktriza, L. (2018). Faktor yang Mempengaruhi Perkembangan Anak Balita Usia 1-2 Tahun di Kota Bukittinggi. REAL in Nursing Journal ( RNJ ), 1(2), 84-94. https://doi.org/http://dx.doi.org/10.32883/rnj.v1i2.264.g92

Saadah, N., Suparji, \& Sulikah. (2020). Stimulasi Perkembangan oleh Ibu melalui Bermain dan rekreasi pada Anak Usia Dini (B. Yulianto (ed.)). Scopindo Media Pustaka.

Sadikin, A., Hamidah, A., Pinang, K., Jl, M., Ma, J., Km, B., Indah, M., Jaluko, K., Kode, K. M., \& Indonesia, P. (2020). Pembelajaran Daring di Tengah Wabah Covid-19 ( Online Learning in the Middle of the Covid-19 Pandemic ). BIODIK: Jurnal IImiah Pendidikan Biologi, 6(1), 214224. https://doi.org/https://doi.org/10.22437/bio.v6i2.9759

Sudarto. (2016). Ketrampilan dan Nilai sebagai Pendidikan dalam perspektif Islam. ,Jurnal Al Lubab, 1(1), 105-120.

Sulisnadewi, N. L. K., Labir, I. K., \& Yunianti, N. L. P. S. (2018). Implementasi Kelas Ibu Balita dalam Meningkatkan Kemampuan Ibu dalam Memberikan Stimulasi Tumbuh Kembang Anak di Kecamatan Sukawati. Jurnal Pengabmas Masyarakat Sehat, 2(1), 45-52. https://doi.org/https://doi.org/10.33992/ms.v2i1.992

Suryahadi, A., Izzati, R. Al, \& Suryadarma, D. (2020). The Impact of COVID-19 Outbreak on Poverty: An Estimation for Indonesia. The SMERU Research Institute. https://smeru.or.id/en/content/impact-covid-19-outbreak-poverty-estimation-indonesia

Suwaryo, P. A. W., \& Yuwono, P. (2017). Faktor-Faktor Yang Mempengaruhi Tingkat Pengetahuan Masyarakat dalam Mitigasi Bencana Alam Tanah Longsor. University Research Colloquium, 305-314.

Tarigan, E. R. (2019). Hubungan Sumber Informasi Dengan Pengetahuan Remaja. 1(2), 107-112.

Tunjung, L., Jati, S., \& Sumarni, W. (2020). Dampak Pandemi Covid-19 Terhadap Perkembangan Anak Sekolah Dasar. Seminar Nasional Pascasarjana UNNES.

Wiresti, R. D. (2020). Analisis Dampak Work From Home pada Anak Usia Dini di Masa Pandemi Covid-19. Jurnal Obsesi: Jurnal Pendidikan Anak Usia Dini, 5(1), 641-653. https://doi.org/10.31004/obsesi.v5i1.563

Yuliana. (2020). Corona virus diseases (Covid-19); sebuah tinjauan literatur. Wellness and Healthy Magazine, 2(February), 187-192. https://doi.org/https://doi.org/10.30604/well.95212020 